\title{
DIGITAL LITERACY COMPETENCES IN IMPROVING THE PROBLEM-SOLVING SKILLS IN FACING THE INDUSTRIAL REVOLUTION 4.0
}

(A Study on Students at Several State and Private Universities in Bandung)

\section{Nining Harnani, Dodi Tisna Amijaya, and Luthfi Setiadiwibawa}

Faculty of Economics and Business, UNWIM, Indonesia,

E-mail: niningharnani@gmail.com; amijaya07@gmail.com; lecturesetiadiwibawa@gmail.com

\begin{abstract}
This study aims to determine student's digital literacy competences in improving the problem-solving skills in facing the era of Industrial Revolution 4.0, which is conducted on students at several state and private universities in Bandung. This study is expected to contribute to determining student's digital literacy competences. The methods used in this study are descriptive and verification methods, in which the data obtained will be turned into numbers, converted into percentages, and then described. The sampling technique used is purposive sampling technique, namely students at colleges and universities, both public and private in Bandung. In this study, the sample used is 300 students. The analytical tool used is regression analysis with the SPSS program. Based on the results of the study, it is found that the digital literacy competences of students in Bandung can be categorized as Good, and the problem-solving skills of students in Bandung can be categorized as Good. The results of regression analysis shown that t-count $(10,902)>t$-table $(1,967)$. This means that the digital literacy competences have an effect on problem-solving skills, in which every change of 1 (one) unit in the digital literacy competences can increase the problem-solving skills by 720 units. Therefore, it can be concluded that the digital literacy competences significantly influence the problem-solving skills.
\end{abstract}

Key words: Digital Literacy; Problem-Solving; Industrial Revolution; student's digital literacy

\section{KOMPETENSI LITERASI DIGITAL DALAM MENINGKATKAN KEMAMPUAN MEMECAHKAN PERMASALAHAN DALAM MENGHADAPI REVOLUSI INDUSTRI 4.0}

\begin{abstract}
ABSTRAK. Penelitian ini bertujuan untuk mengetahui kemampuan Literasi digital mahasiswa dalam meningkatkan kemampuan memecahkan permasalahan dalam menghadapi Era Revolusi Industri 4.0 di beberapa perguruan tinggi Negri maupun Swasta di Kota Bandung. Metode yang digunakan dalam penelitian ini adalah metode penelitian deskriptif dan verifikatif dimana data yang diperoleh akan diangkaan dan diprosentasekan lalu dideskripsikan. Sedangkan teknik pengambilan sampel yang digunakan adalah teknik pengambilan sampel secara purposive sampling yaitu mahasiswa di perguruan tinggi dan universitas baik negri maupun swasta di kota Bandung. Dalam Penelitian ini sampel yang dipergunakan adalah sebanyak 300 orang. Alat analisis yang digunakan adalah analisis Regresi dengan program SPSS. Berdasarkan hasil penelitian diperoleh bahwa kemampuan liyterasi digital mahasiswa di kota Bandung dapat dikategorikan Baik, dan kemampuan memecahkan masalah mahasiswa di kota Bandung dapat dikategorikan Baik, Berdasarkan hasil analisis regresi dapat diketahui bahwa thitung $10.902>t$ table 1.967. Maka dapat disimpulkan bahwa kompetensi literasi digital berpengaruh terhadap kemampuan memecahkan masalah. dimana setiap perubahan 1 satuan pada kemampuan kompetensi Literasi Digital dapat meningkatkan kemampuan memecahkan masalah sebesar 720 satuan. Maka dapat disimpulkan bahwa kompetensi literasi digital dipengaruhi secara signifikan oleh kemampuan memecahkan masalah.
\end{abstract}

Kata Kunci : Literasi Digital; Memecahkan Masalah; Revolusi Industri; digital literasi mahasiswa

\section{INTRODUCTION}

Results of a survey shown that $92.6 \%$ of students are internet users (APJI Indonesia, 2019). Students have the potential to use social media and other digital media to develop their abilities, both critical understanding and active participation, which benefit the society in digital media.

Students must be prepared to face the big challenges in the era of Industrial Revolution 4.0. One of the big challenges is to have skills and competences that are relevant to this new era and in accordance with the new working patterns created in the Industrial Revolution 4.0. One important factor is skills and competences that must be consistently improved. The Industrial Revolution 4.0 is an integration of the uses of internet with assembly lines in the industrial world. The uses of information technology are now very widespread in society, especially among students. Therefore, students are required to have digital literacy competences, so that they can take advantage of information technology, for example to solve complex problems that occur in everyday life, especially to solve problems in lectures. Educational institutions must be able to produce graduates with character, competence, and innovation. On the other hand, the generation living in the era of Industrial Revolution 4.0 must have high competitiveness. Apart from excelling in academics, the current generation must also be highly competitive in facing life's challenges.

(Bawden, D (2001:21) explains that digital literacy is the ability to understand and use information from various digital sources that is 
presented through computers. In line with Bawden, Gilster (1997: 3) explains that in digital literacy, critical thinking is needed to evaluate information that is found through digital sources. In addition to critical thinking, the competence required is learning how to organize knowledge and build a reliable set of information from several different sources.

Hague and Payton in Akbar \& Anggraeni (2017) explain that digital literacy can be interpreted as the ability of an individual to apply functional skills to digital devices so that he can find and select information, think critically, create creativity, collaborate with others, communicate effectively, and still pay attention to electronic security and the evolving socio-cultural context. In the book entitled "Materi Pendukung Literasi Digital (2017:8), digital literacy is defined as life skills that not only involve the ability to use technology, information, and communication devices, but also the ability to socialize, to learn, to have attitudes, to think critically, to be creative, and to be inspirational as digital competences. Digital literacy is the ability that a person has in using digital devices to access, understand, analyze, and evaluate existing information critically and selectively.

From the definitions of digital literacy above, since students cannot be separated from access to information technology, it is expected that they have good digital literacy competences so that they can access, understand, analyze, and evaluate information obtained critically and selectively.

Every day we are faced with problems that must be solved. Problem solving involves methods and skills to find the best solution in solving a problem. Problem solving is very important because we live in a world full of choices and we have to make decisions. Likewise, students are expected to have the ability to solve very complex problems both in learning and in everyday life. Analytical thinking and problem-solving skills are part of the ability to solve problems.

According to Matlin, as quoted by Herlambang (2013), problem solving is needed when we want to achieve certain goals but the way to achieve them is not clear. In other words, if a student is trained to solve a certain problem, the student will have good skills in producing appropriate information, analyzing information, and realizing how necessary it is to re-examine the results obtained.

Students are one of the nation's generations, who will be the pillars of continuing Indonesia's development in the future. The quality of human resources in the era of Industrial Revolution 4.0 absolutely needs to be improved, so that in the future
Indonesia can compete with other nations through its best generations. This is what underlies this study entitled 'Students' Digital Literacy Competences in Improving Problem-Solving Skills in Facing the Era of Industrial Revolution 4.0" (A Study on Students at Several State and Private Universities in Bandung).

This study was conducted with the aims of:

1. Determining the digital literacy competences of students in Bandung.

2. Determining the problem-solving skills of students in Bandung.

3. Determining the effects of digital literacy competences on problem-solving skills of students in Bandung.

By conducting this research, we want to determine students' digital literacy competences, so that it is expected to be able to improve students' skills in solving the problems they face in the era of Industrial Revolution 4.0. It is hoped that students will be able to have high competitiveness in the increasingly fierce competition today.

It is expected that the results of this study can find several ways to improve students' problems-solving skills through their digital literacy competences, so that students will have critical and analytical thinking and problem-solving skills.

\section{Digital Literacy}

In this era of information and communication technology that continues to develop so fast, digital literacy competences are important to have, so that everyone is able to take advantage of the opportunities that these developments bring. Leu, Jr. et al. (2005:1572) describe that the literacy of the new era contains several skills that are considered important. The idea of Leu, Jr. et al. gives us some characteristics of the new literacy as the ability to:

1. Adapt to new technology

2. Use information technology in personal and professional life

3. Identify important questions

4. Find information that is in accordance with the questions

5. Evaluate the information

6. Communicate the information to others

In relation to digital media, literacy is an individual competence related to the ability to access digital media itself. Obtaining information, analyzing content, and being able to create new information resulting from interactions with digital technology are forms of digital media literacy.

Coiro (2003:1) suggests that the nature of literacy itself can change rapidly when new 
technology enters society. The definition of literacy according to Coiro has developed as the ability to learn, understand, and interact with technology in a meaningful way. Digital literacy is often referred to by various names, including internet literacy, computer literacy, information technology literacy, ICT literacy or e-literacy.

Based on these descriptions, digital literacy can be simply defined as the ability to understand and use digital devices as a form of mediated communication in various aspects of everyday life.

Glen \& Royston (2009:123) argue that technological literacy includes the skills and abilities of individuals and communities to use digital technology and the Internet effectively to address their socio-economic and political needs.

Hobbs (2010:19) maps five competences in digital literacy, among others:

1. Access, namely the competence to search using media and technology and to share appropriate and relevant information with others.

2. Analyze and evaluate, namely understanding the message and using critical thinking to analyze message quality, honesty, credibility, and point of view, then considering the potential effect or consequence of the message.

3. Create, that includes writing or producing content using creativity and confidence to express oneself, supported by a sense of purpose, readership, and composition techniques.

4. Reflect, namely applying social responsibility and ethical principles of one's own identity and life experience in their communication behavior.

5. Act, namely working individually and collectively to share knowledge and solve problems in the family, workplace and community, and participate as members of society at the local, regional, national, and international levels.

\section{Definition of Digital Literacy}

Bawden, D (2001:21) explains that digital literacy is the ability to understand and use information from various digital sources that is presented through computers. In line with Bawden, Gilster (1997: 3) explains that in digital literacy, critical thinking is needed to evaluate information that is found through digital sources. In addition to critical thinking, the competence required is learning how to organize knowledge and build a reliable set of information from several different sources. Hague and Payton in Akbar \& Anggraeni (2017:31) explain that digital literacy can be interpreted as the ability of an individual to apply functional skills to digital devices so that he can find and select information, think critically, create creativity, collaborate with others, communicate effectively, and still pay attention to electronic security and the evolving socio-cultural context. In the book entitled "Materi Pendukung Literasi Digital (2017:8), digital literacy is defined as life skills that not only involve the ability to use technology, information, and communication devices, but also the ability to socialize, to learn, to have attitudes, to think critically, to be creative, and to be inspirational as digital competences. Digital literacy is the ability that a person has in using digital devices to access, understand, analyze, and evaluate existing information critically and selectively.

\section{Digital Literacy Competences}

Gilster (1997: 3) classifies digital literacy competences into four competences that a person needs to have to be said digital literate, as follows:

1. Internet Searching, namely a person's ability to use the internet and perform various activities in it. This competence includes two components, among others:

a. The ability to search for information on the internet using search engines, and

b. The ability to perform various activities in it.

2. Hypertextual Navigation, namely skills to read and understand the navigation of a hypertext in a web browser. This competence includes four components, among others:

a. Knowledge of hypertext and hyperlinks and how they work,

b. Knowledge of the differences between reading a textbook and browsing via the internet,

c. Knowledge of how the web works, and

d. The ability to understand the characteristics of web pages.

3. Content Evaluation, namely a person's ability to think critically and provide an assessment of what is found online that is accompanied by the ability to identify the validity and completeness of the information referenced by hypertext links. This competence includes five components, among others:

a. The ability to distinguish between views and contents, that is user's perception of understanding the appearance of a visited web page,

b. The ability to analyze the background of information on the internet, namely the awareness to trace further the sources and producers of information,

c. The ability to evaluate a web address by understanding the types of domains for each particular institution or country,

d. The ability to evaluate a web page, and 
e. Knowledge of FAQ in a newsgroup or discussion group.

4. Knowledge Assembly, namely the ability to organize knowledge and to build a collection of information obtained from various sources with the ability to collect and evaluate facts and opinions properly and without prejudice. This competence includes four components, among others:

a. The ability to search for information via the internet,

b. The ability to create a personal newsfeed or the latest news notifications that will be obtained by joining and subscribing to news in a newsgroup, mailing list, or other discussion group that discusses certain topics according to specific needs or topics,

c. Ability to crosscheck or double-check the information obtained,

d. The ability to use all types of media to prove the truth of information, and

e. The ability to compile the sources of information obtained on the internet with real life that are not connected to the network.

All digital literacy competences can be used in the operation of Google, Instagram, etc. because Google and Instagram operate using the internet. Simply understanding how to use Google cannot be said to have digital literacy competence. Therefore, the improvement of all personal abilities related to digital literacy competences in operating Instagram is very necessary so that social media abuse does not occur. Based on the theoretical basis above, the researchers establish the theory by Paul Gilster (1997: 3) regarding digital literacy competence as a unit of analysis that will be used as a tool to analyze how digital literacy competences on Google are.

Based on research conducted by Prijana, Asep (2016:1), when compared to students with a lower GPA, the higher the reading skills of students, the higher their GPA.

\section{Problem-Solving Skills}

According to Newell and Simon, as quoted by Darminto (2010: 24), "a problem is a situation where an individual wants to take the necessary actions to get what he wants". A problem that comes to someone causes that person to at least try to solve the problem he is facing, so that he has to use various ways such as thinking, trying, and asking questions to solve the problem. Even in this case, the process of solving problems between one person and another may be different. According to Saad \&
Ghani in M.Imamuddin (2018:45), problem solving is a planned process that must be carried out in order to get a certain solution to a problem that may not be obtained immediately. Polya in M.Imamuddin (2018:45) defines problem solving as an attempt to find a way out of a difficulty. Meanwhile, Sajadi et al., (2013:7) in their research results reveals that, "the problem-solving process is one of the important elements in combining real-life problems".

According to Matlin, as quoted by Herlambang (2013: 17), problem solving is needed when we want to achieve certain goals but the way to achieve them is not clear. In other words, if a student is trained to solve a certain problem, the student will have good skills in producing appropriate information, analyzing information, and realizing how necessary it is to re-examine the results obtained.

According to Polya in M.Imamuddin, 2018:5), there are four stages of problem solving, namely understanding the problem, planning problem solving, carrying out the plan, and reviewing the results obtained. The four stages of problem solving by Polya are as follows:

1. Understand the problem. The first stage in problem solving is understanding the problem. Students need to identify what they know, what is there, numbers, relationships and associated values, and what they are looking for. Some suggestions that can help students understand complex problems are asking questions about what is known and sought, explaining problems in their own words, relating the problems to other similar problems, focusing on important parts of the problem, developing models, and drawing diagrams.

2. Devise a plan. Students need to identify the operations involved and the strategies required to solve the problem. This can be done by students in ways such as: guessing, developing a model, sketching diagrams, simplifying problems, identifying patterns, making tables, experimenting and simulating, working in reverse, testing all possibilities, identifying sub-objectives, making analogies, and sorting data or information.

3. Carry out the plan. What is implemented obviously depends on what has been planned before and also includes the following things: interpreting the information provided in mathematical form and executing the strategy during the process and calculation. In general, at this stage students need to maintain the plan they have chosen. If such a plan cannot be implemented, students can choose another method or plan.

4. Looking back. The following aspects need to be considered when rechecking the steps previously 
involved in solving the problem, namely: checking all important information that has been identified, checking all the calculations that have been involved, considering whether the solution is logical, looking at other alternative solutions, and reading back question and asking yourself if the question is really answered.

According to Krulik and Rudnick, as quoted by Carson (2007:21-22) there are five stages of problem solving, namely:

1. Read. The activities carried out by students at this stage are writing down keywords, asking other students about the problem, or stating the problem back into language that is easier to understand.

2. Explore. This process includes searching for patterns to determine the concept or principle of the problem. At this stage students identify the problem, present the problem in an easy to understand way. The question that is used at this stage is, "what is the problem like"?

3. Select a strategy. At this stage, students draw conclusions or make hypotheses about how to solve the problems, based on what has been obtained in the first two stages.

4. Solve the problem. At this stage all mathematical skills, such as counting, are carried out to find an answer.

5. Review and extend. At this stage, students check their answers again and see variations in how to solve the problem.

Dewey, as cited by Carson (2008: 39), explains the level of problem solving as follows:

1. Confront a problem, namely feeling a difficulty. This stage can involve realizing what is not yet known and frustration at the vagueness of the situation.

2. Define the problem, namely clarifying the characteristics of the situation. This stage includes the activity of specifying what is known and not known, finding goals, and identifying standard and extreme conditions.

3. Find a solution, namely looking for a solution. This stage can include observing patterns, identifying steps in planning, and selecting or finding algorithms.

4. Consequence of alleged solution, namely carrying out plans for the alleged solution. Such as using existing algorithms, collecting additional data, performing needs analysis, reformulating problems, testing for similar situations, and getting results (answers).

5. Test the consequence, namely testing whether the problem definition fits the situation or not. This stage can include the activity of evaluating whether the hypotheses are appropriate or not, the data used is correct or not, the analysis used is correct or not, the analysis is suitable for the existing data types or not, the results are reasonable or not, and the plan used is applicable on another matter or not.

\section{METHOD}

The method used in this research is quantitative method which describe in descriptive and verification analyses. Descriptive analysis is a method that provides an explanation to report the state of a company, this method is used to draw general conclusions. Meanwhile, verification analysis is to test hypotheses and predictions using simple linear regression statistical tests because both data sources are ordinal.

Observations were made on students at several private and public universities. The research was conducted at several public and private universities in Bandung.

The population studied are students at several state and private universities in Bandung. Roscoe in Sugiyono (2017: 91) states that the minimum sample size in research that uses statistical data analysis methods is 30 . In this study the number of samples is 300 students, by using purposive sampling technique due to limitations and adjusted to the ability of the researchers. In this study, the questionnaire was distributed to students at several universities that researchers could meet such as ITB, Unpad, UPI, Unpas, Widyatama, Unisba, Unwim, Al Gifari University, and Telkom University. Due to the COVID-19 pandemic, the researchers' movements were somewhat limited.

Data collection can be done in a variety of settings, sources, and methods. When viewed in terms of data source, data collection can use primary and secondary sources, namely from literature studies and questionnaires.

Primary sources are data sources that directly provide data to data collectors, for example data from other people or documents. Furthermore, when viewed in terms of data collection methods or techniques, data collection techniques can be carried out by interview, questionnaire, observation, and a combination of the three.

Data sources in this study are primary and secondary data. Meanwhile, the data collection method is using questionnaire, interview, documentation, and observation techniques. 


\section{RESULT AND DISCUSSION}

\section{Digital Literacy Competences of Students in Bandung}

The percentage of digital literacy competences of students in Bandung is obtained by dividing the total score of the respondent's answer by the maximum total score of the respondent's answer, then multiplying by 100 .

$$
\text { Level of digital literacy competences }=\frac{\text { total score of respondent's answer }}{\text { maximum total score of respondent's answer }}
$$

Level of digital literacy competences $=\frac{12.407}{15.000} \times 100=82,71 \%$

The data processing resulted in the level of digital literacy competences of students in Bandung of $82.7 \%$. Regarding the level of knowledge, the level of digital literacy competences of students in Bandung is $82.7 \%$, which is in the Good category. The percentage level of digital literacy competences of students in Bandung is said to be good if it is in the range of $76 \%-100 \%$, sufficient if it is in the range of $56 \%-75 \%$, and less if it is $<55 \%$ (Arikunto, 2010).

Based on the results of descriptive data processing from the research questionnaire that was successfully distributed to 300 respondents, it is found that the digital literacy competences of students in Bandung is Good. Meanwhile, the results of study on students' literacy competences, which is based on Hobbs's 5 (five) mappings of literacy competences, are as follows:

a. Digital Literacy Competences of Students in Bandung in the Aspect of Access.

Based on the results of descriptive data processing from the research questionnaire, it is found that the Digital Literacy Competences of Students in Bandung in the aspect of Access can be categorized as Good, in which as many as $48.6 \%$ of students are able to find and get the information through digital media and $53.4 \%$ of students are able to understand the information they get through digital media.

b. Digital Literacy Competences of Students in Bandung in the Aspect of Analyze and Evaluate.

Based on the results of descriptive data processing from the research questionnaire, it is found that the Digital Literacy Competences of Students in Bandung in the aspect of Analyze and evaluate can be categorized as Good, in which as many as $49.6 \%$ of students have critical thinking in understanding the information they get through digital media and $42 \%$ of students are able to analyze the quality of messages and the correctness of the information they get through digital media.

c. Digital Literacy Competences of Students in Bandung in the Aspect of Create.

Based on the results of descriptive data processing from the research questionnaire, it is found that the Digital Literacy Competences of Students in Bandung in the aspect of Create can be categorized as Good Enough, in which as many as $34.6 \%$ of students are able to write messages or create content using creativity through digital media and $37 \%$ of students are able to share experiences by writing through digital media.

d. Digital Literacy Competences of Students in Bandung in the Aspect of Reflect.

Based on the results of descriptive data processing from the research questionnaire, it is found that the Digital Literacy Competences of Students in Bandung in the aspect of Reflect can be categorized as Good, in which as many as $62.6 \%$ of students are able to use good ethics in using digital media and $60 \%$ of students are able to implement social responsibility in using digital media.

e. Digital Literacy Competences of Students in Bandung in the Aspect of Act.

Based on the results of descriptive data processing from the research questionnaire, it is found that the Digital Literacy Competences of Students in Bandung in the aspect of Act can be categorized as Good Enough, in which as many as $47.3 \%$ of students are able to use digital media in order to participate in organizational or community activities and $60 \%$ of students are able to use digital media to share knowledge in solving personal and/or community problems.

Based on the discussion above, it can be seen that the digital literacy competences of students in Bandung is considered Good, but the smallest score is in the aspect of Create. The finding suggests that digital literacy competences, especially in the aspect of Create (writing), need to be improved and it is expected that in the future there will be special learning in the context of writing. The improvement in the aspect of students' writing competence, especially in digital media, is expected will make student writing useful particularly in solving problems faced in the community.

\section{Problem-Solving Skills of Students in Bandung}

The percentage of problem-solving skills of students in Bandung is obtained by dividing 
the total score of the respondent's answer by the maximum total score of the respondent's answer, then multiplying by 100 .

$$
\text { Level of problem - solving skills }=\frac{\text { total score of respondent's answer }}{\text { maximum total score of respondent's answer }}
$$

Level of problem - solving skills $=\frac{12.013}{15.000} \times 100=80,08 \%$

The data processing resulted in the level of problem-solving skills of students in Bandung of $80.08 \%$. Regarding the level of knowledge, the level of problem-solving skills of students in Bandung is $80.08 \%$, which is in the Good category. The percentage level of problem-solving skills of students in Bandung is said to be good if it is in the range of $76 \%-100 \%$, sufficient if it is in the range of $56 \%$ $-75 \%$, and less if it is $<55 \%$ (Arikunto, 2010).

Based on the results of descriptive data processing from the research questionnaire that was successfully distributed to 300 respondents, it is found that the problem-solving skills of students in Bandung is Good. Meanwhile, the results of study on students' problem-solving skills, which is based on Krulik and Rudnick's 5 (five) stages of problem solving, are as follows:

a. Problem-Solving Skills of Students in Bandung in the Aspect of Read and Understand Problems on Digital Media.

Based on the results of descriptive data processing from the research questionnaire, it is found that the Problem-Solving Skills of Students in Bandung in the aspect of Read and Understand Problems on Digital Media can be categorized as Good, in which as many as $32 \%$ of students are very able to read and understand, $34.67 \%$ students are able to read and understand, $25.33 \%$ are quite able to read and understand, 5.67 are less able to read and understand, and $2.33 \%$ are not able to read and understand problems on digital media.

b. Problem-Solving Skills of Students in Bandung in the Aspect of Explore Information on the Digital Media.

Based on the results of descriptive data processing from the research questionnaire, it is found that the Problem-Solving Skills of Students in Bandung in the aspect of Explore Information on Digital Media can be categorized as Good, in which as many as $46.33 \%$ of students are very able to explore information, $36.67 \%$ of students are able to explore information, $13.33 \%$ of students are quite able to explore information, $3 \%$ are less able to explore information, and $0.67 \%$ are not able to explore information on digital media. c. Problem-Solving Skills of Students in Bandung in the Aspect of Find the Right Strategy on the Digital Media.

Based on the results of descriptive data processing from the research questionnaire, it is found that the Problem-Solving Skills of Students in Bandung in the aspect of Find the Right Strategy on Digital Media can be categorized as Good, in which as many as $27 \%$ of students are very able to find the right strategy, $44.67 \%$ of students are able to find the right strategy, $22.67 \%$ of students are quite able to find the right strategy, 5\% are less able to find the right strategy, and $0.67 \%$ are not able to find the right strategy on digital media.

d. Problem-Solving Skills of Students in Bandung in the Aspect of Find Solutions to Solve Problems on the Digital Media.

Based on the results of descriptive data processing from the research questionnaire, it is found that the Problem-Solving Skills of Students in Bandung in the aspect of Find Solutions to Solve Problems on Digital Media can be categorized as Good, in which as many as $22.33 \%$ of students are very able to find solutions to solve problems, $41 \%$ of students are able to find solutions to solve problems, $30.33 \%$ of students are quite able to find solutions to solve problems, 5.33\% are less able to find solutions to solve problems, and $1 \%$ are not able to find solutions to solve problems on digital media.

e. Problem-Solving Skills of Students in Bandung in the Aspect of Review the Problems through Information on the Digital Media.

Based on the results of descriptive data processing from the research questionnaire, it is found that the Problem-Solving Skills of Students in Bandung in the aspect of Review Problems through Information on Digital Media can be categorized as Good, in which as many as 35.33\% of students are very able to review the problems through information, $40.67 \%$ of students are able to review the problems through information, $21.33 \%$ of students are quite able to review the problems through information, $2.33 \%$ are less able to review the problems through information, and $0.33 \%$ are not able to review the problems through information on digital media.

\section{Regression Analysis}

The Regression Model is shown in Table 3, so that it is obtained the Regression Model as follows: $\mathrm{Y}=9.720+720 \mathrm{X}$. This means that without the Problem-Solving Skills, the Digital Literacy Competences have a value of 9,720, and each 
increase in the Problem-Solving Skills by 1 unit will increase the Digital Literacy Competences by 10,440 units.

Table 1. Regression Coefficient

\begin{tabular}{cccccr}
\hline \multirow{2}{*}{$\begin{array}{c}\text { Model } \\
\text { B }\end{array}$} & \multicolumn{2}{c}{$\begin{array}{c}\text { Unstandardized } \\
\text { Coefficients }\end{array}$} & $\begin{array}{c}\text { Standardized } \\
\text { Coefficients }\end{array}$ & \multicolumn{1}{c}{$\mathrm{t}$} \\
\cline { 3 - 5 } & & $\begin{array}{c}\text { Std. } \\
\text { Error }\end{array}$ & Beta & & \\
\hline 1 & (Constant) & 9,720 & 2,478 & & 3,923 \\
& $\begin{array}{l}\text { Digital } \\
\text { Literacy }\end{array}$ &, 720 &, 066 &, 534 & 10,902 \\
Competences & & & & \\
\hline
\end{tabular}

\section{Correlation Analysis}

The correlation between Digital Literacy Competences and Problem-Solving Skills of Students in Bandung is shown in the results of data processing in the following table:

Table 2. Analisis Corelation

\begin{tabular}{|c|c|c|c|c|c|}
\hline \multicolumn{6}{|c|}{ Model Summary ${ }^{a}$} \\
\hline Model & $\mathrm{R}$ & $\begin{array}{c}\mathrm{R} \\
\text { Square }\end{array}$ & $\begin{array}{l}\text { Adj R } \\
\text { Square }\end{array}$ & $\begin{array}{l}\text { Std. Error } \\
\text { of the } \\
\text { Estimate }\end{array}$ & $\begin{array}{l}\text { Durbin- } \\
\text { Watson }\end{array}$ \\
\hline 1 &, $534^{\mathrm{a}}$ & 285 & 283 & 5,76637 & 1,956 \\
\hline \multicolumn{6}{|c|}{ a. Predictors: (Constant), Digital Literacy Competences } \\
\hline \multicolumn{6}{|c|}{ b. Dependent Variable: Problem-Solving Skills } \\
\hline
\end{tabular}

Based on table 2, the correlation is shown by the R-value which is equal to 0.534 , meaning that Digital Literacy Competences have a strong enough relationship. It is based on the interpretation of the correlation coefficient according to Hasan (2006: 99).

\section{Coefficient of Determination}

The amount of the coefficient of determination is shown in table 2 on the R-square value, which is 0.285 or $28.5 \%$. This value implies that the digital literacy competences affect the problem-solving skills by $28.5 \%$, while the rest is influenced by other factors that are not examined in this study.

\section{Hypothesis Test}

The t-test is conducted to determine whether the digital literacy competence and the problem-solving skills have a significant relationship or not. Based on table 1 , it can be seen that the t-count is 10,902 with sig $0.00<0.005$. Therefore, it can be concluded that the digital literacy competence is significantly influenced by the problem-solving skills.

\section{CONCLUSION}

The digital literacy competences of students in Bandung are categorized as good, and it is expected that students can improve their competences in writing on digital media. The problem-solving skills of students in Bandung are categorized as Good, and digital media has a large enough role in increasing creativity and innovation in solving problems. It is expected that there will be more in-depth research regarding methods of increasing literacy competence, especially in the field of writing, so that it is hoped that students will be able to share their knowledge through writing on digital media.

\section{ACKNOWLEDGEMENT}

We extend our acknowledgement to:

1. LLDIKTI that has provided the opportunity to carry out research through the PDP grant scheme

2. The Rector and staffs of Winaya Mukti University

3. The Head and staffs of the LPPM that have assisted morally and technically

4. The Dean and staffs of the Faculty of Economics and Business that have provided motivation

5. The fellow lecturers for discussions

\section{REFERENCES}

Akbar, M.F. \& Anggraeni, F.D. (2017). Teknologi Dalam Pendidikan : Literasi Digital dan SelfDirected Learning pada Mahasiswa Skripsi. Indigenous: Jurnal Ilmiah Psikologi, 2, (1), 28-38. https://doi.org/10.23917/indigenous. v1i1.4458

Arikunto, S. 2010. Prosedur Penelitian Suatu Pendekatan Praktik. Jakarta: Rineka Cipta

APJI Indonesia. (2019). Penetrasi \& Profil Perilaku Pengguna Internet Indonesia. Apjii, 51. https://apjii.or.id/survei2018s/download/ TK5oJYBSyd8iqHA2eCh4FsGELm3ubj

Bawden, D. (2001). Progress in documentation information and digital literacies: a review of concepts. 57, (2), 218-259.

Buckingham, M. \& Vosburgh, R.M. (2001, December). The 21st century Human Resources function: it's the talent, stupid! Identifying and developing talent, one person at a time, becomes our defining challenge. Human Resource Planning, 24, (4), 17+. https://link.gale.com/apps/doc/A84345752/ $\mathrm{E} ? \mathrm{u}=$ anon $\sim \mathrm{ed} 277020 \& \mathrm{sid}=$ googleScholar\&x id $=$ bb207de4

Carson, J. (2007). A Problem With Problem Solving: Teaching Thinking Without Teaching Knowledge. Mathematics Educator, 17, (2), 7-14. 
Coiro, J. (2003). Exploring Literacy on the Internet comprehension to encompass new literacies. The Reading Teacher, 56, (5), 458-464. http:// www.jstor.org/stable/20205224

Coiro, J., Knobel, M., Lankshear, C., \& Leu, D.J. (2008). Central Issues in New Literacies and New Literacies Research. In J. Coiro, M. Knobel, C. Lankshear, and D.J. Leu (Eds.), Handbook of Research in New Literacies (pp. 1 -21). Mahwah, NJ: Erlbaum.

Creeber, G. \& Martin, R (ed.). (2009). Digital Cultures: Understanding New Media, Berkshire-England: Open University Press.

Darminto, B.P. (2010). Peningkatan Kreativitas dan Pemecahan Masalah bagi Calon Guru Matematika melalui Pembelajaran Model Treffinger. Makalah dipresentasikan pada Seminar Nasional Matematika dan PendidikanMatematika. Yogyakarta, 27 November 2010.

Gilster. (1997). Digital Literacy. New York: Wiley.

Glen, C. \& Royston, M. (2009). Digital Cultures understanding new media. In Mc Graw Hill. http://books.google. com/books/about/Digital_cultures. html?id=MTnhAAAAMAAJ

Hasan. M.I. (2006). Pokok-pokok Materi Metode Penelitian dan Aplikasinya. PT Ghalia Jakarta.

Herlambang. (2013). Analisis Kemampuan Pemecahan Masalah Matematika Siswa Kelas vii SMP negeri 1 Kepahiang Tentang Bangun datar Ditinjau Dari Teori Van Hiele. Tesis Program Sarjana Pendidikan Matematika FKIP Universitas Bengkulu, h. 14.

Hobbs, R. (2010). Digital_and_Media_Literacy_A_ Plan_of_Action.pdf.
Imamuddin, M.I. (2018). Proses Berpikir Mahasiswa Quitter Dalam Menyelesaikan Masalah Geometri Dengan Pemberian Scaffolding Di Jurusan Pendidikan Matematika Iain Bukittinggi. Sainstek: Jurnal Sains Dan Teknologi, 9, (1), 40. https://doi.org/10.31958/ js.v9i1.618

Leu, Jr., D. J., Kinzer, C. K., Coiro, J. \& Cammack, D. W. (2005). Toward a Theory of New Literacies Emerging From the Internet and Other Information and Communication Technologies. July 2015, 1570-1613. https:// doi.org/10.1598/0872075028.54

Nasrullah, R., Aditya, W., Satya, T.I., Nento, M.N., Hanifah, N., Miftahussururi \& Akbari, Q.S. (2017). Materi Pendukung Literasi Digital: Gerakan Literasi Nasional. Kementerian Pendidikan Dan Kebudayaan, 33. https:// gln.kemdikbud.go.id/glnsite/wp-content/ uploads/2017/10/cover-materi-pendukungliterasi-finansial-gabung.pdf

Prijana \& Rohman, A.S. (2016). Kemampuan Baca Mahasiswa pada Buku Teks. Sosiohumaniora, 18, (3), 255-260. https://doi.org/10.24198/ sosiohumaniora.v18i3.10324

Polya, G. (1973). How to Solve it. New Jersey: Princeton University Press

Sajadi, M., Amiripour, P. \& Rostamy-Malkhalifeh, M. (2013). The Examinig Mathematical Word Problems Solving Ability under Efficient Representation Aspect. Mathematics Education Trends and Research, 2013, 1-11. https://doi.org/10.5899/2013/metr-00007

Sugiyono. (2017). Metode Penelitian Pendidikan Pendekatan Kuantitatif, Kualitatif, dan R\&D. Bandung: Alfabeta. 